DOI 10.14746/ssp.2017.3.10

\author{
Anna KoŁomycew \\ Uniwersytet Rzeszowski
}

\title{
Uspołecznienie procesu realizacji zadań oświatowych jako forma racjonalizacji polityki publicznej gmin ${ }^{1}$
}

Streszczenie: Polityka oświatowa jest obecnie jedną z kluczowych polityk publicznych realizowanych na poziomie lokalnym. Wynika to z jej kosztochłonności, specyficznej konstrukcji, łączącej kompetencje władz lokalnych i centralnych, a także znaczenia jakie ma edukacja w procesach rozwoju społeczeństwa i państwa. W przypadku obszarów wiejskich dodatkowym czynnikiem jest pozaedukacyjna rola szkół w życiu wspólnoty lokalnej. Próbując sprostać realizacji zadań z zakresu polityki oświatowej, władze gmin podejmują się różnych działań racjonalizatorskich. Jednym z nich jest uspołecznienie oświaty, rozumiane jako włączenie podmiotów niepublicznych w proces realizacji zadań oświatowych (uspołecznienie faktyczne). Na podstawie wyników przeprowadzonych badań ilościowych i jakościowych, autorka przedstawia warunki formalno-prawne przekazania zadań oświatowych podmiotom niepublicznym, skalę procesu uspołecznienia oraz warunki i okoliczności, jakie do tego doprowadziły. Wyniki badań wskazują, że proces ten pomimo pozornie jasnych rozwiązań prawnych, w praktyce jest rzadkością i napotyka szereg trudności zarówno po stronie sektora publicznego, jak i społecznego.

Słowa kluczowe: uspołecznienie, polityka oświatowa, polityka publiczna, usługi publiczne, prywatyzacja

\section{Wstęp}

Droblematyka uspołecznienia szkolnictwa jest podejmowana wraz z każdą reformą polityki oświatowej i planowanymi zmianami w systemie zarządzania szkołami. Uspołecznienie szkolnictwa utożsamiane jest z procesami decentralizacji i demokratyzacji szkoły. W praktyce jednak,

${ }^{1} \mathrm{~W}$ artykule wykorzystane zostały wyniki badań realizowanych w ramach projektu pt. Interes polityczny a racjonalność w realizacji polityki publicznej. Polityczne i społeczne konsekwencje optymalizacji sieci szkół, nr 2015/19/D/HS5/03153, finansowanego ze środków Narodowego Centrum Nauki w ramach konkursu SONATA 10. 
najczęściej jest rozumiane jako włączenie czynnika społecznego w procesy zarządzania szkołą i wpływu otoczenia szkoły (interesariuszy) na model kształcenia i wychowania uczniów. Proces uspołecznienia rzadko dotyczy całej polityki oświatowej, a więc udziału podmiotów pozapublicznych zarówno na etapie koncepcyjnym, decyzyjnym, jak również w fazie zarządzania szkołą i realizacji zadań oświatowych.

Zmiany wprowadzane od kilku lat w systemie polityki oświatowej w Polsce tylko pozornie demokratyzują system szkolnictwa. Pomimo wdrożenia kolejnych rozwiązań pozwalających na włączanie podmiotów społecznych w oddziaływanie na kształt edukacji, nadal utrzymane zostają relikty porządku centralistycznego. Zdaniem D. Sześciło, w przypadku decentralizowania oświaty, w Polsce mamy do czynienia z działaniami, które określić można jako „dwa kroki do przodu, jeden do tyłu”. Z jednej strony podejmowane są działania władz centralnych zmierzające do decentralizacji i zwiększenia swobody władz lokalnych w realizacji polityki oświatowej oraz uspołecznienia szkół poprzez wprowadzenie takich rozwiązań instytucjonalnych jak np. rady rodziców, rady szkół czy rady oświatowe (Sześciło 2016, s. 33). Z drugiej zaś, widoczne jest silne uzależnienie systemu szkolnictwa i kształtu sieci szkół od decyzji organów nadzoru, które wręcz uniemożliwiają racjonalne kreowanie i realizowanie polityki oświatowej, a przez to - z uwagi na wysokie koszty polityki oświatowej - wręcz paraliżują działania w obrębie innych polityk publicznych.

W niniejszym artykule autorka przedstawia formy uspołecznienia polityki oświatowej, przy czym proces uspołeczniania rozumie szerzej niż tylko jako formalny udział interesariuszy (społecznych) w bieżącym funkcjonowaniu szkoły ${ }^{2}$. Szerokie rozumienie uspołecznienia szkolnictwa obejmuje: po pierwsze udział podmiotów niepublicznych w procesach kreowania polityki oświatowej ${ }^{3}$, a po drugie ich pełne uczestnictwo

${ }^{2}$ Konstrukcja podmiotów społecznych przewidzianych w prawie oświatowym nie do końca pozwala określać ich zaangażowanie w działalność szkoły jako „zarządzanie”. $\mathrm{Za} Ł$. Sułkowskim wskazać można funkcje zarządzania tj. działanie (podejmowanie decyzji), sprawowanie władzy (zarządzanie właściwe w ramach struktury organizacyjnej) oraz dysponowanie zasobami organizacji (Sułkowski 2005, s. 20-23; por. Gawroński 2010, s. 24-25). Z uwagi na to, że przewidziane w prawie oświatowym podmioty mają faktycznie kompetencje doradcze, opiniodawcze i tylko częściowo inicjatywne i kontrolne, zasadne jest - w odniesieniu do ich udziału w ramach systemu szkolnictwa - posługiwanie się określeniem „udział w bieżącym funkcjonowaniu szkoły”.

3 Określenie „kreowanie polityki oświatowej” należy rozumieć jako tworzenie założeń polityki oświatowej i wskazywanie kierunków rozwoju szkolnictwa po- 
w realizacji zadań oświatowych. W niniejszym artykule kluczowe znaczenie ma drugi wymiar uspołecznienia, czyli uczestnictwo podmiotów niepublicznych w realizacji zadań oświatowych. W tym znaczeniu, uspołecznienie jest bliższe koprodukcji usług edukacyjnych niż partycypacji społecznej w znacznie mniej angażujących formach, do których zaliczyć można udział w ciałach konsultacyjnych i opiniodawczo-doradczych takich jak rady rodziców, rady szkoły czy rady oświatowe (przy organach samorządowych).

Bazując na wynikach przeprowadzonych badań ${ }^{4}$, analizie aktów normatywnych, źródeł zastanych i raportów na temat oświaty, autorka koncentruje się na problematyce udziału podmiotów pozapublicznych (niepublicznych - głównie stowarzyszeń) w realizacji polityki oświatowej.

Celem artykułu jest opis i wyjaśnienie - na podstawie zidentyfikowanych przypadków - sytuacji (okoliczności), w których uspołecznienie (oznaczające przejęcie szkoły przez podmiot niepubliczny) stało się elementem procesu racjonalizacji polityki oświatowej gmin. Teza postawiona przez autorkę zakłada, że uspołecznienie polityki oświatowej zawężone do możliwości udziału w kolegialnych ciałach opiniodawczych,

wszechnego. Autorka ma świadomość, iż podmiotami odpowiedzialnymi za tworzenie polityki oświatowej w Polsce są właściwe władze centralne i lokalne (gminne w zakresie szkolnictwa na poziomie podstawowym). Niemniej jednak w obecnym porządku prawnym przewidziane zostały rozwiązania zakładające udział podmiotów społecznych w polityce oświatowej, nie tylko na etapie realizacji, ale także w fazie koncepcyjnej i kreacyjnej np. rady oświatowe (Gozdowska, Uryga, 2015). Uwzględnianie opinii tych podmiotów, jak również opinii całej społeczności lokalnej (uzyskanej w drodze konsultacji) autorka uznaje za przejaw uspołecznienia procesu kreowania polityki oświatowej.

${ }^{4}$ Badania jakościowe prowadzone w formie wywiadów półustrukturyzowanych w oparciu o przygotowany kwestionariusz wywiadu. Dobór zarówno województw, gmin, jak i respondentów do badania miał charakter celowy i był realizowany w dwóch etapach. W etapie I dokonano wyboru województw, w których - zgodnie z danymi udostępnionymi przez MEN - w latach 2006-2014 zlikwidowano największą liczbę szkół (świętokrzyskie), najmniejszą (pomorskie) i średnią (mazowieckie). W drugim etapie dokonano wyboru gmin do badań jakościowych biorąc pod uwagę dwa czynniki: likwidację szkół oraz zmiany na stanowisku wójta/burmistrza. Ostatecznie do badania wybrano 12 gmin (10 gmin wiejskich i 2 miejsko-wiejskie), w których przeprowadzono łącznie 60 wywiadów. Wśród respondentów znaleźli się przedstawiciele władz lokalnych - organów wykonawczych i członków rad gmin, środowisk społecznych, nauczycieli, podmiotów niepublicznych prowadzących szkoły oraz przedstawiciele środowiska lokalnego. 
doradczych i konsultacyjnych ma charakter pozorny. O faktycznym uspołecznieniu polityki oświatowej można mówić w momencie dysponowania przez podmioty niepubliczne możliwością realnego udziału w wykonywaniu zadań oświatowych, co wiąże się z ponoszeniem odpowiedzialności, nakładem środków i ryzykiem. Ramy teoretyczne niniejszego artykutu wyznacza koncepcja uspołecznienia ${ }^{5}$.

\section{Uspołecznienie oświaty - szczytny cel, pozorny charakter}

Kolejne zmiany w obrębie polityki oświatowej wprowadzane na przestrzeni ostatnich lat realizowano pod hasłami decentralizacji i zwiększenia możliwości oddziaływania na system zarządzania oraz charakter szkoły (w tym w kwestiach dotyczących spraw wychowawczych i edukacyjnych) przez podmioty społeczne, tj. nauczycieli, rodziców i uczniów. Jak wskazał K. Waligórski (1997, s. 265-266), zagadnienie uspołecznienia szkół należy rozpatrywać $\mathrm{w}$ dwóch wymiarach tj. wewnętrznym i zewnętrznym. Wymiar wewnętrzny obejmuje działania zmierzające do wypracowania wewnętrznych rozwiązań regulacyjnych, które pozwalaja na efektywne zarządzanie szkoła, w tym takie kwestie jak sposób podejmowania decyzji, konsultowanie zmian czy formy komunikacji pomiędzy zaangażowanymi podmiotami. Celem uspołeczniania powinna być tu optymalizacja efektywności i sprawności szkół, ukierunkowana na dalszy rozwój dotychczasowej działalności (Waligórski, 1997, s. 267). W tym wymiarze kluczowe będzie funkcjonowanie takich instytucji społecznych w strukturze szkół, jakimi są rady pedagogiczne, rady rodziców czy rady szkół, a także styl zarządzania oraz model przywództwa realizowany przez dyrektora szkoły. Istotne z punktu widzenia uspołecznienia będą: wpływ społecznych ciał kolegialnych na zapadające decyzje, model relacji pomiędzy podmiotami społecznymi a dyrekcją szkoły, sposób kreowania ciał społecznych (oddolny, odgórny), a także poziom zaangażowania społeczności związanej z daną szkołą (Waligórski, 1997, s. 267). Wymiar ten dotyczy zatem środowiska szkolnego, na które jak wskazał

${ }^{5}$ W niniejszym tekście autorka koncentruje się na uspołecznieniu realizacji zadań oświatowych, które utożsamia z koprodukcją usług publicznych. W tym kontekście można mówić o uspołecznieniu polityki oświatowej. Pomija natomiast ten aspekt uspołecznienia, który dotyczy zarządzania szkołą, a więc kolegialny udział ciał społecznych takich jak rady rodziców czy rady szkół pełniące funkcje podmiotów opiniodawczo-doradczych (Sześciło, 2015, s. 116-117; por. Szarfenberg 2016). 
Waligórski składają się nauczyciele, rodzice oraz uczniowie. Należy jednak uwzględnić także rolę organów prowadzących.

Zdaniem B. Śliwerskiego, uspołecznienie nie jest celem samym w sobie. Powinno służyć poprawie efektywności działań edukacyjnych i wychowawczych realizowanych przez szkoły. Większa swoboda decyzyjna przyznana szkołom, a w konsekwencji ich wewnętrznym podmiotom, może sprzyjać poprawie efektywności kształcenia poprzez zwiększenie motywacji, samodzielności i niezależności (Śliwerski, 2013, s. 19).

W praktyce jednak kompetencje wewnętrznych organów szkół nie są aż tak rozległe i trudno określić zakres ich faktycznego oddziaływania z uwagi na nieprecyzyjne przepisy oraz brak wiedzy i zaangażowania społeczności w sprawy szkoły (Kopińska, 2013, s. 168-181; Mencel, 2013, s. 336-339). Dlatego uspołecznienie o charakterze wewnętrznym uznać zależy za uspołecznienie formalne (pozorne), bądź uspołecznienie w wymiarze konsultacyjno-opiniodawczo-doradczym. Nie jest to forma uspołecznienia pełnego (faktycznego), które wiązałoby się z realną możliwością podejmowania decyzji, realizacji zadań z zakresu oświaty i ponoszeniem odpowiedzialności.

$\mathrm{W}$ przypadku uspołecznienia w wymiarze zewnętrznym, istotne jest oddziaływanie szkoły (i efektów kształcenia) na procesy rozwoju zachodzące w jednostce lokalnej, wpływ na lokalną społeczność i całe otoczenie. Warto jednak zaznaczyć, że uspołecznienie powinno mieć charakter dwukierunkowy. Nie chodzi wyłącznie o „oddziaływanie szkoły” na otoczenie, ale raczej o współpracę środowiska szkolnego z jego otoczeniem i tworzenie sieci kontaktów i współpracę. Zdaniem K. Waligórskiego, uspołecznienie w tym wymiarze ma zapobiegać wytworzeniu się dystansu pomiędzy szkołą a społecznością lokalną. Powinno tworzyć warunki dla partycypacji w sferze publicznej, a także pełnić funkcję prewencyjną przed centralizowaniem oświaty. Tak rozumiane uspołecznienie można utożsamiać z „usamorządowieniem”, a więc angażowaniem wspólnoty lokalnej w działania publiczne (Waligórski, 1997, s. 267; Kwiatkowski, 2008, s. 49-50).

Odnosząc się do zewnętrznego wymiaru uspołecznienia oświaty można wskazać, że istniejące w Polsce rozwiązania prawno-instytucjonalne pozwalają na faktyczny udział podmiotów społecznych w realizacji polityki oświatowej. Pierwszym z istniejących rozwiązań jest możliwość tworzenia rad oświatowych, mających charakter fakultatywnych podmiotów doradczych (opiniodawczych, inicjatywnych) przy organie stanowiącym gminy (art. 48 u.o.s.o.). I choć koncepcja powoływania rad oświatowych 
jako społecznych ciał doradczych mogących oddziaływać na procesy kreowania polityki oświatowej w gminach wydawała się słuszna, to sposób umocowania tych podmiotów spowodował, że w praktyce są one rzadkością bez większego wpływu na politykę oświatową gmin (Gozdowska, Uryga, 2015, s. 8).

Drugim rozwiązaniem może być prowadzenie szkół przez podmioty niepubliczne ${ }^{6}$, a więc uczestnictwo w procesie świadczenia usług publicznych. W tym znaczeniu uspołecznienie jest bliskie koprodukcji, rozumianej jako dobrowolne zaangażowanie społeczeństwa w proces świadczenia usług, zmierzający do poprawy ich dostępności i jakości (Sześciło, 2015, s. 76-88). Włączenie podmiotów niepublicznych w system realizacji usług publicznych wiąże się z długofalowym zobowiązaniem, odpowiedzialnością i ryzykiem, jak również koniecznością współpracy z sektorem publicznym. Za pełną formę uspołecznienia uznać można rozwiązanie umożliwiające przekazanie małych szkół (liczących do 70 uczniów) podmiotom niepublicznym. Problemy finansowe i organizacyjne związane z ich utrzymaniem stały się powodem ich likwidacji przez samorządy gminne. Groźba utraty szkoły, która w społecznościach wiejskich poza funkcjami edukacyjnymi

${ }^{6}$ Należy rozróżnić podmioty niepubliczne prowadzące szkoły niepubliczne oraz podmioty niepubliczne prowadzące szkoły na prawach szkół publicznych, które podjęły się samodzielnie takiego zadania, bądź też zadanie to zostało im przekazane na mocy art. 5, ust. 5g u.o.s.o. (dotyczy to tzw. małych szkół liczących do 70 uczniów). W niniejszym artykule autorka koncentruje się wyłącznie na drugim rozwiązaniu, a więc funkcjonowaniu szkół prowadzonych przez stowarzyszenie, przy czym rozwiazzanie to wynika albo z likwidacji szkoły prowadzonej przez JST i ponownego jej otwarcia jako szkoły tzw. stowarzyszeniowej lub bezpośredniego przekazania szkoły stowarzyszeniu (bez jej formalnej likwidacji) na mocy umowy zgodnie ze wspominanym artykułem u.o.s.o.

7 Termin „mała szkoła” nie jest precyzyjny, mimo iż w literaturze dotyczącej polityki oświatowej funkcjonuje od wielu lat. Najczęściej „małe szkoły” są utożsamiane $\mathrm{z}$,niewielką” liczbą uczniów lub nauczycieli. Kategoria ta wciąż jest nieostra, bowiem nie precyzuje ilości uczniów, która pozwalałyby klasyfikować szkołę jako małą. Szerzej: Pęczkowski, 2017, s. 11-21. W niniejszym artykule posługując się terminem „,mała szkoła" autorka odnosi się do szkół liczących poniżej 70 uczniów, które zgodnie z przepisami art. 5 ust. $5 \mathrm{~g}$ u.o.s.o. mogły zostać przekazane podmiotom niepublicznym w drodze umowy. Takie szkoły były likwidowane w większości badanych gmin. Wyjątkiem było województwo pomorskie, w którym zlikwidowano także szkoły liczące około 100 uczniów, a które zdaniem władz samorządowych były małe i nieekonomiczne. Odmienne podejście do wielkości szkół i organizacji sieci szkolnej w regionach wynika z uwarunkowań historycznych i ukształtowanej sieci placówek edukacyjnych. Por. Kuriański, 2008, s. 199-200. Jednocześnie posługując się terminem „mała szkoła” autorka odnosi go do szkół zlokalizowanych wyłącznie na terenie gmin wiejskich i miejsko-wiejskich. 
często pełniła także funkcje integracyjne i miała charakter sentymentalny, stała się czynnikiem mobilizującym środowisko lokalne do aktywnego włączenia się $\mathrm{w}$ proces realizacji zadań oświatowych i podjęcia się prowadzenia szkoły. Ta forma uspołecznienia będzie stanowiła przedmiot dalszych rozważań niniejszego tekstu.

\section{Prowadzenie szkół przez podmioty niepubliczne jako przykład faktycznego uspołecznienia polityki publicznej}

Obowiązujące obecnie w Polsce przepisy przewidują możliwość prowadzenia szkół przez podmioty inne niż publiczne. D. Kurzyna-Chmiel wskazuje, iż udział organizacji pozarządowych w procesach realizacji zadań publicznych oznacza właśnie uspołecznienie administracji. Procesy te $\mathrm{z}$ kolei prowadzą do prywatyzacji zadań publicznych, co przejawia się zmianą podmiotu będącego bezpośrednim wykonawcą zadań publicznych (lub/i dostarczycielem usług publicznych) z publicznego na niepubliczny. Działania te świadczą o decentralizacji administracji publicznej (Kurzyna-Chmiel, 2013, s. 259; Wlaźlak, 2010, s. 111).

Uspołecznienie i prywatyzacja usług publicznych są konsekwencją coraz większej liczby zadań nakładanych na jednostki samorządu terytorialnego oraz rosnących oczekiwań społecznych. Powoduje to, że samorządy coraz częściej nie są w stanie sprostać wyzwaniom zarówno finansowo, jak i organizacyjnie (Benington, 2006, s. 12; Leoński, 2006, s. 166). To z kolei wymusza współdziałanie sektora publicznego z podmiotami niepublicznymi (Kurzyna-Chmiel, 2013, s. 259; KurzynaChmiel, 2012, s. 111-127). Trudno w tym przypadku mówić o dobrowolnej współpracy równych podmiotów zmierzających do osiagnięcia określonego celu (Biernat, 1979, s. 38-39). Współpraca w zakresie realizacji zadań oświatowych okazuje się być ratunkiem dla samorządów, przy czym przekazanie realizacji zadań publicznych nie zwalnia podmiotów publicznych z odpowiedzialności za nie. Należy wskazać, że polityka oświatowa stanowi szczególne obciążenie dla budżetów gmin wiejskich i miejsko-wiejskich, w których wydatki oświatowe stanowią średnio 42\% ogółu wydatków bieżących, ale zdarzają się gminy, w których sięgają nawet 60\% (BDL GUS, 2017; NIK, 2014). W takich sytuacjach poszukiwanie rozwiązań - w tym współpraca z podmiotami niepublicznymi - pozwalających „odciążyć” budżet jest naturalne. Trudno jednak mówić o równości zaangażowanych stron czy faktycznie wspólnym celu, gdyż 
w przypadku przekazania szkół motywy działań zaangażowanych stron są odmienne (Kapuścińska, 2014, s. 14; Strus, 2016, s. 228-230).

W 2009 roku ustawodawca wprowadził możliwość przekazania szkoły liczącej do 70 uczniów (tzw. małej szkoły) osobie prawnej lub fizycznej na podstawie uchwały rady gminy zgodnie ze znowelizowanym art. 5 ust. 5 g ustawy o systemie oświaty (Dz. U. 2009, Nr 56, poz. 458 z późn. $\mathrm{zm}$.). Takie rozwiązanie nie jest tożsame z prowadzeniem szkoły przez inne podmioty niepubliczne. Wprowadzony mechanizm miał zapobiec likwidacji małych szkół (samorządowych), zlokalizowanych głównie na obszarach wiejskich. Jak wskazuje A. Kozińska-Bałdyga, pomimo działań racjonalizatorskich (w formie likwidacji szkół) zwłaszcza w gminach wiejskich, rozpoczętych pod koniec lat 90 . XX wieku, nadal szkoły zlokalizowane na wsiach stanowią największy odsetek szkół w Polsce. W 2012 roku stanowiły aż 69\%, a w 2015 - 67,57\% ogółu szkół podstawowych w Polsce. I choć - jak wskazuje przywołana autorka - problemy szkół w skali kraju mają charakter uniwersalny, to w przypadku szkół wiejskich pojawia się szereg problemów niespotykanych w środowisku miejskim (Kozińska-Bałdyga, 2014, s. 7; GUS, 2015, s. 68). Zaliczyć do nich należy przede wszystkim specyfikę środowisk wiejskich, pozaedukacyjne funkcje pełnione przez szkoły na wsi tj. integracyjne i kulturowe, a także sentymentalne znaczenie szkół, które często powstawały w ramach czynów społecznych (Marzec-Holka, 2015, s. 154; Tołwińska-Królikowska, 2011; Ochnio, 2011; Odpowiedź; Kozanecki, 2016). Małe szkoły na obszarach wiejskich są postrzegane jako centrum życia wsi (Kwieciński, 2011, s. 423), świadczą o rozwoju danej miejscowości i wpływają na jej rangę i rozwój (Pilch, 2007, s. 15).

Jak wskazała D. Kurzyna-Chmiel, przekazanie szkoły do prowadzenia organowi niepublicznemu należy traktować jako czynność prawną z zakresu prawa cywilnego, w przypadku której zaangażowane podmioty wyrażają (dobrowolnie) chęć z jednej strony przejęcia, a z drugiej przekazania zadań publicznych (Kurzyna-Chmiel, 2013, s. 299). Istotą tego rozwiązania jest zachowanie przez gminę nadzoru i kontroli nad realizacją zadań wynikających z zawartej umowy. Rozwiązanie to jest przejawem samodzielności jednostki samorządu, ale z uwagi na niedookreśloność przepisów np. W zakresie wyboru podmiotu niepublicznego, któremu przekazywana jest szkoła, może prowadzić do nadmiernej swobody i patologii, co sygnalizowano od początku wprowadzenia takiej możliwości realizacji zadań publicznych (Kurzyna-Chmiel, 2013, s. 299; Majchrowicz-Jopek, 2012, s. 164-181). 
Podstawą przekazania szkoły podmiotowi niepublicznemu jest wspomniany już art. 5 ust. $5 \mathrm{~g}$ u.o.s.o. zgodnie z którym, rada gminy może podjać uchwałę pozwalającą na przekazanie w drodze umowy szkoły liczącej do 70 uczniów $^{8}$ podmiotowi niepublicznemu bez konieczności jej formalnej likwidacji. Warunkiem przekazania szkoły jest pozytywna opinia właściwego kuratora oświaty, zatem uchwała rady gminy ma charakter „,intencyjny”, ale i jest warunkiem wydania opinii przez organ nadzoru. Jego pozytywna opinia jest podstawą do zawarcia umowy z podmiotem niepublicznym, czyli osobą fizyczną lub prawną niebędącą jednostką samorządu terytorialnego, a więc np. stowarzyszeniem. Zawierana umowa określa szereg kwestii m.in. ustanowienie lub nie obwodu szkolnego, warunki przyjmowania uczniów, reguluje kwestie nadzoru JST nad szkoła, bowiem na samorządzie nadal spoczywa obowiązek realizacji zadania oświatowego, warunki korzystania z mienia, zasady sprawozdawczości i przeprowadzania kontroli, warunki rozwiązania umowy i przejęcia szkoły tzw. ,zwrotne” przejęcie. Rozwiązanie to nakłada na władze samorządowe szereg obowiązków związanych z poinformowaniem rodziców oraz nauczycieli, a także uregulowanie kwestii rozwiązania ich umów. Przekazanie szkoły zmienia warunki zatrudniania kadry (dyrektora i nauczycieli) oraz warunki ich pracy. Podmiot niepubliczny nie ma też prawa zlikwidować szkoły (Kuratorium; Majewska, 2015, s. 28-34). Obowiązujące przepisy w zasadzie nie nakładają żadnych szczególnych wymagań (przygotowanie merytoryczne, doświadczenie, określone wykształcenie) na podmiot niepubliczny, który deklaruje chęć przejęcia szkoły. Jak wskazuje D. Sześciło w przepisach pominięto również kwestie dysponowania odpowiednim kapitałem przez zainteresowany podmiot czy posiadania zabezpieczenia finansowego. Ustawodawca nie nałożył też obowiązku przeprowadzania weryfikacji zdolności podmiotu niepublicznego ubiegającego się o przejęcie szkoły przez samorząd do prowadzenia tego rodzaju działań (Sześciło, 2015a). Dlatego też należy zgodzić się z K. Majewską, która zaleca ostrożne korzystanie $\mathrm{z}$ tego rozwiązania. $\mathrm{Z}$ jednej strony jest ono formą partycypacji w realizacji zadań publicznych, ma chronić małe szkoły wiejskie przed likwidacją i tym samym zabezpieczać ich rolę w środowisku lokalnym, ale jednocześnie sprawa dotyczy szczególnie wrażliwej kwestii, jaką jest edukacja dzieci. Istotnym jest też fakt pozostawienia odpowiedzialności za realizację tego zadania publicznego $\mathrm{w}$ gestii samorządów, które po-

${ }^{8}$ Zgodnie z wyrokiem WSA w Łodzi z 13 kwietnia 2012 r., III SA/Łd 158/12 do liczby uczniów szkoły wlicza się także dzieci z oddziału przedszkolnego o ile funkcjonował w szkole. 
winny współpracować z wiarygodnym i odpowiedzialnym podmiotem. Najczęściej są to lokalne organizacje, współtworzone przez mieszkańców (Majewska, 2015, s. 34).

Należy jednak wskazać, że mechanizm przekazania szkoły nie zwalnia władz gminy z realizacji zadań oświatowych i w zasadzie nakłada obowiązek stałej współpracy z podmiotem niepublicznym. Ustawodawca przewidział również mechanizm zabezpieczający na wypadek niewywiązania się podmiotu przejmującego szkołę z obowiązku realizacji zadań oświatowych. W takiej sytuacji w dalszym ciągu spoczywa on na władzach gminy, które zmuszone są podjąć się dalszego prowadzenia szkoły (Majewska, 2015, s. 34-36). Rozwiązanie to nie pozwala zatem zupełnie „pozbyć” się problemu, jaki dla samorządów stanowią (małe) szkoły, ale odciąża je finansowo. Przekazanie szkoły podmiotowi niepublicznemu, który podejmuje się realizacji zadania publicznego, jakim jest oświata, uznać należy za formę pełnego uspołecznienia. Podmiot podejmujący się takiego zadania czyni to dobrowolnie i realizuje zadanie nieodpłatnie (szkoła zachowuje status szkoły publicznej) (Majewska, 2015, s. 37). Ten element odróżnia szkoły przekazane przez JST podmiotom niepublicznym od szkół niepublicznych ${ }^{9}$.

Mechanizm dopuszczający przejęcie szkoły przez nowopowstałe lub istniejące już stowarzyszenie (np. lokalne) czy osobę fizyczną (najczęściej związaną ze szkołą np. dotychczasowy dyrektor czy nauczyciel) miał sprzyjać aktywizacji społecznej i mobilizacji wspólnoty lokalnej. Ponadto wskazywano, że sam proces przekazania szkoły, wymuszając kontakty społeczności lokalnej z władzami gminy, może sprzyjać współpracy, która z kolei może przełożyć się na inne sfery funkcjonowania gminy (Kozińska-Bałdyga, 2015, s. 22-23).

\section{Uspołecznienie realizacji zadań oświatowych - racjonalność czy kalkulacja polityczna?}

Głównym argumentem przemawiającym za racjonalizacją sieci szkół były kwestie finansowe, wynikające z wysokich kosztów prowadzenia

9 Takie rozwiązanie przewidują przepisy ustawy o systemie oświaty, której art. 5 pkt 1 i pkt 2 wskazuje, że na system szkolnictwa w Polsce składają szkoły (i placówki) publiczne i niepubliczne, które mogą być prowadzone przez jednostkę samorządu terytorialnego, inną niż samorząd osobę prawną oraz osobę fizyczną (Dz. U. 2004, Nr 256, poz. 2572 z późn. zm.). 
polityki oświatowej. Wysokie koszty generowała nieadekwatna do aktualnych potrzeb i sytuacji demograficznej sieć gminnych szkół, a co za tym idzie koszty osobowe związane z utrzymaniem kadry nauczycielskiej (Herczyński, Sobotka, 2014, s. 22). Wskazać należy, że zarządzanie siecią szkół podstawowych jest zadaniem własnym samorządów. Pod pojęciem sieci szkół należy rozumieć układ szkół i placówek oświatowych na terenie danej jednostki administracyjnej. Jak wskazują J. Herczyński i A. Sobotka na sieć szkół składają się takie elementy jak liczba uczniów, stopień organizacyjny, kadra, a także relacje pomiędzy poszczególnymi szkołami. Elementy te oddziałują na proces zarządzania oświatą, który obejmuje planowanie sieci, tworzenie/likwidację szkół (w tym przekazywanie innym podmiotom), wyznaczanie obwodów oraz organizację dowozu dzieci do szkół (Herczyński, Sobotka, 2014, s. 9-10; Dziemianowicz-Bąk, Dzierzgowski, 2014, s. 5-6).

Sieć szkół nieadekwatna do współczesnych potrzeb gmin, zwłaszcza na terenach wiejskich była istotnym obciążeniem dla budżetów samorządowych (Kaczyńska, 2017, s. 143; NIK, 2015). W dużej mierze jest ona - pomimo podejmowanych od kilku lat intensywnych działań racjonalizacyjnych przez samorządy - efektem poprzedniego systemu oraz przemian zmierzających do decentralizacji polityki oświatowej następujących w latach 90. XX wieku. Konieczność zmiany organizacji sieci szkół jest powiązana ze zmianami demograficznymi, które skutkują obniżeniem liczby uczniów, zwłaszcza małych szkół zlokalizowanych na obszarach wiejskich (Marzec-Holka, 2015, s. 147-161).

Najprostszym rozwiązaniem - z punktu widzenia samorządów - byłaby likwidacja szkół generujących koszty niewspółmierne do liczby uczniów. Jednak likwidacja tych szkół - będąca najbardziej radykalną formą racjonalizacji - mogłaby się okazać niezwykle kosztowana dla władz gmin w wymiarze politycznym i społecznym (Kotarba, 2014, s. 58-59). Rozwiązanie, jakim jest przekazanie szkoły organowi niepublicznemu - pomimo wprowadzonych podstaw prawnych - nie ma charakteru powszechnego. Trudno oszacować skalę zastosowania tego mechanizmu, co potwierdzają zarówno badania przeprowadzone przez J. Herczyńskiego i A. Sobotkę, jak i autorkę niniejszego artykułu. Jak wskazują J. Herczyński i A. Sobotka, problem z ustaleniem czy szkoła została przekazana w drodze art. 5 ust. $5 \mathrm{~g}$ ustawy o szkolnictwie wyższym, czy „,bez umowy", a więc po uprzedniej formalnej likwidacji szkoły prowadzonej przez JST, a następnie powołaniu szkoły stowarzyszeniowej, wynika ze specyfiki danych gromadzonych w Systemie Informacji Oświatowej, gdzie 
nie jest wskazany sposób w jaki podmiot niepubliczny podjął się prowadzenia szkoły (oddolna inicjatywa po likwidacji szkoły publicznej, czy przekazanie w drodze art. 5 ust. 5g u.o.s.o) (Herczyński, Sobotka, 2014, s. 18). Tymczasem sposób przekazania szkoły jest istotny dla dalszych losów danej placówki oraz relacji pomiędzy podmiotem niepublicznym prowadzącym szkołę a władzami gminy.

Biorąc pod uwagę ogólne dane ilościowe dotyczące organów prowadzących szkoły można dostrzec na przestrzeni ostatniej dekady tendencję do zmniejszania się odsetka szkół podstawowych prowadzonych przez gminy, a wzrost odsetka szkół (o charakterze publicznym) prowadzonych przez podmioty niepubliczne (zob. wykres 1 ).

\section{Wykres 1. Zmiana organów prowadzących szkoły w latach 2006-2016}

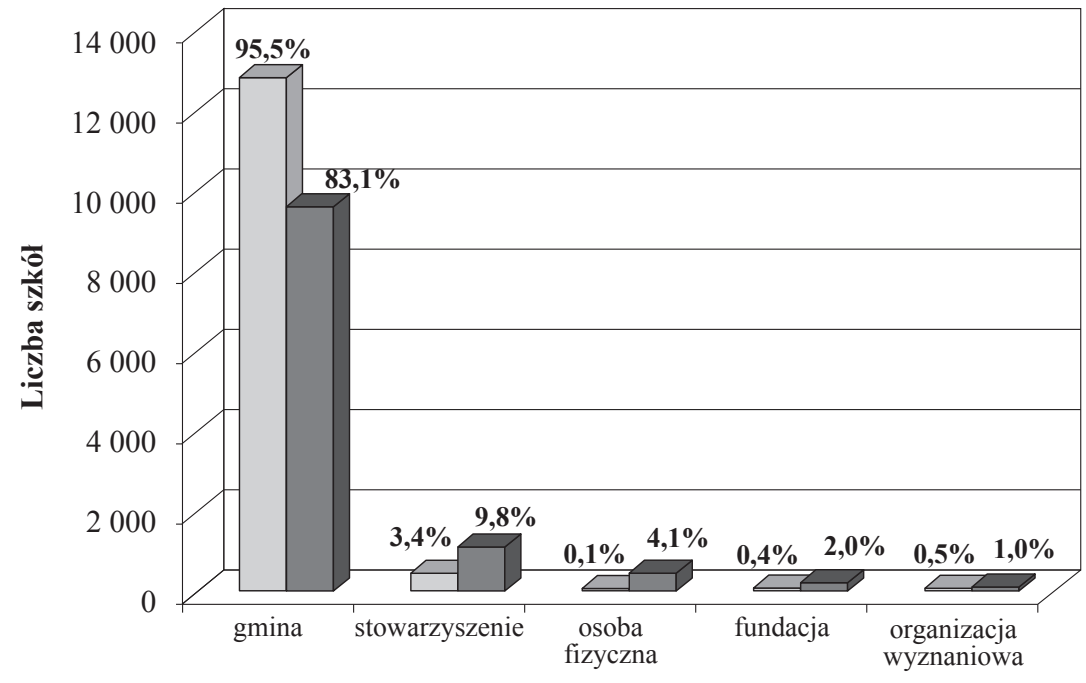

Organ prowadzący

$\square$ Liczba szkół wg organu prowadzącego w 2006 r.

Liczba szkół wg organu prowadzącego w 2016 r.

Źródło: Opracowanie własne na podstawie danych SIO w latach 2006-2016.

Zmniejszenie odsetka szkół prowadzonych przez gminy nie oznacza, że zostały one bezpośrednio przekazane podmiotom niepublicznym. Zmniejszenie liczby szkół prowadzonych przez gminy jest także efektem ich likwidacji (w tym samoczynnego wygaszenia ze względu na brak uczniów). Jednocześnie wzrost odsetka szkół prowadzonych przez 
stowarzyszenia nie świadczy, iż podmioty te przejmowały szkoły bezpośrednio od gmin (por. Herczyński, Sobotka, 2014, s. 86-87). W tej grupie są również szkoły zakładane i od początku prowadzone przez stowarzyszenia. Dane wskazane na powyższym wykresie pokazują ogólną tendencję do przejmowania zadań publicznych (w tym przypadku oświatowych) przez podmioty niepubliczne, która wpisuje się w koncepcję uspołeczniania i koprodukcji zadań publicznych. Najbardziej aktywnym rodzajem podmiotów niepublicznych, decydujących się na prowadzenie szkół (publicznych), jak i ich przejmowanie od samorządów były stowarzyszenia. Włączenie tych podmiotów w proces realizacji zadań publicznych miało przede wszystkim zmniejszyć koszty prowadzenia szkół, analogicznie jak w przypadku włączania podmiotów niepublicznych w realizację innego rodzaju zadań publicznych (Sześciło, 2015b, s. 15). Podstawową cechą szkół prowadzonych przez stowarzyszenia był brak obowiązku stosowania Karty Nauczyciela jako podstawy zatrudnienia kadry dydaktycznej, a to właśnie koszty wynagrodzenia nauczycieli stanowiły największe obciążenie budżetów gmin. Należy też wskazać, że stowarzyszenia mogą być znacznie bardziej skuteczne w realizacji zadań z uwagi na mniejsze zbiurokratyzowanie niż podmioty sektora publicznego. Ponadto z uwagi na społeczny cel działalności, podmioty te korzystają z różnego rodzaju zasobów, w tym z wolontariuszy (w przypadku szkół najczęściej rodziców uczniów) (Lipka-Szostak, 2012). Niewątpliwe przekazanie szkoły stowarzyszeniu wiąże się z szeregiem zalet, ale i trudności, do których zaliczyć można chociażby wybór odpowiedniego stowarzyszenia - zewnętrzne - bardziej profesjonalne i doświadczone czy lokalne - znające specyfikę środowiska i potrzeby wspólnoty. Z tym też wiąże się problem trwałości i pewności świadczenia usług edukacyjnych (Kozińska-Bałyga, 2015a, s. 19-23).

Należy wskazać, że udział podmiotów niepublicznych w procesie świadczenia usług edukacyjnych był silnie zróżnicowany regionalnie (zob. tab. 1).

Tabela 1

Odsetek szkól prowadzonych przez stowarzyszenia w latach 2006-2016 wg województw

\begin{tabular}{||c|c|c|c|}
\hline \multicolumn{1}{|c|}{ Województwo } & $\mathbf{2 0 0 6}$ & $\mathbf{2 0 1 6}$ & Zmiana \\
\hline 1 & 2 & 3 & 4 \\
\hline Dolnośląskie & 4,4 & 7,6 & $+3,2$ \\
\hline Kujawsko-pomorskie & 2,6 & 7,2 & $+4,6$ \\
\hline
\end{tabular}




\begin{tabular}{||l|c|c|c|}
\hline \multicolumn{1}{|c|}{1} & 2 & 3 & 4 \\
\hline Lubelskie & 3,4 & 15,3 & $+11,9$ \\
\hline Lubuskie & 4,4 & 8,9 & $+4,5$ \\
\hline Łódzkie & 3,0 & 8,4 & $+5,4$ \\
\hline Małopolskie & 2,8 & 7,6 & $+4,8$ \\
\hline Mazowieckie & 5,0 & 9,2 & $+4,2$ \\
\hline Opolskie & 6,3 & 16,6 & $+10,3$ \\
\hline Podkarpackie & 1,4 & 8,9 & $+7,5$ \\
\hline Podlaskie & 6,5 & 13,3 & $+6,8$ \\
\hline Pomorskie & 3,0 & 6,6 & $+3,6$ \\
\hline Śląskie & 3,8 & 9,1 & $+5,3$ \\
\hline Świętokrzyskie & 4,2 & 17,4 & $+13,2$ \\
\hline Warmińsko-mazurskie & 3,3 & 11,7 & $+8,4$ \\
\hline Wielkopolskie & 0,6 & 9,3 & $+8,7$ \\
\hline Zachodniopomorskie & 2,9 & 5,4 & $+2,5$ \\
\hline \hline
\end{tabular}

Źródło: Opracowanie własne na podstawie danych SIO za lata 2006-2016.

Z powyższego zestawienia wynika, że największy wzrost odsetka szkół prowadzonych przez stowarzyszenia na przestrzeni minionej dekady zaobserwowano w województwie świętokrzyskim. Jednocześnie podmioty niepubliczne prowadzące szkoły w tym województwie miały lokalny charakter i tworzone były przez społeczność związaną z daną szkołą. Wśród badanych gmin nie praktykowano przekazywania szkół podmiotom niepublicznym z zewnątrz tj. spoza danej gminy. Wyraźny wzrost odnotowano także w gminach województw opolskiego, lubelskiego, a także podkarpackiego. Nieznacznie wzrósł odsetek szkół prowadzonych przez stowarzyszenia w województwach zachodniopomorskim, pomorskim i dolnośląskim. Można wskazać, że najwięcej szkół prowadzonych przez podmioty niepubliczne (stowarzyszenia) zlokalizowanych było w południowo-wschodniej Polsce, zaś najmniej w północno-zachodniej i centralnej części kraju. Jednym z powodów takiego rozwiązania była specyfika sieci szkół. W przypadku polski południowo-wschodniej sieć była znacznie bardziej rozdrobniona i składała się z małych (liczących nawet do kilkunastu uczniów) szkół. Co więcej, jak wskazuje Związek Nauczycielstwa Polskiego, w przypadku niektórych powiatów małe szkoły stanowiły blisko połowę ogółu istniejących szkół (ZNP, 2015). 
Tabela 2

Liczba szkół i uczniów wg województw w roku szkolnym 2015/2016

\begin{tabular}{||l|c|c|c|}
\hline \hline & $\begin{array}{c}\text { Liczba szkól } \\
\text { podstawowych }\end{array}$ & Liczba uczniów & $\begin{array}{c}\text { Średnia liczba } \\
\text { uczniów w szkole }\end{array}$ \\
\hline Polska & 13563 & 2480793 & 182,90 \\
\hline Dolnośląskie & 803 & 173893 & 216,55 \\
\hline Kujawsko-pomorskie & 686 & 136404 & 198,84 \\
\hline Lubelskie & 971 & 135232 & 139,27 \\
\hline Lubuskie & 339 & 67324 & 198,59 \\
\hline Łódzkie & 840 & 151776 & 180,68 \\
\hline Małopolskie & 1461 & 220561 & 150,96 \\
\hline Mazowieckie & 1774 & 369931 & 208,53 \\
\hline Oppolskie & 397 & 55687 & 140,27 \\
\hline Podkarpackie & 1087 & 133895 & 123,17 \\
\hline Podlaskie & 416 & 72526 & 174,34 \\
\hline Pomorskie & 709 & 162126 & 228,67 \\
\hline Śląskie & 1267 & 279560 & 220,64 \\
\hline Świętokrzyskie & 564 & 74704 & 132,45 \\
\hline Warmińsko-mazurskie & 536 & 93910 & 175,20 \\
\hline Wielkopolskie & 1223 & 247900 & 202,69 \\
\hline Zachodniopomorskie & 496 & 105364 & 212,43 \\
\hline
\end{tabular}

Źródło: Opracowanie własne na podstawie: Oświata $i$ wychowanie $w$ roku szkolnym 2015/2016, Główny Urząd Statystyczny, Warszawa 2016, s. 167-171.

W kontekście faktycznego uspołeczniania realizacji zadań oświatowych i świadczenia usług edukacyjnych przez podmioty niepubliczne - w tym głównie stowarzyszenia - pojawia się szereg trudności, zagrożeń i ryzyko dotyczące zapewnienia ciągłości i pewności usług publicznych (Sześciło, 2014, s. 5-13; Goodman, Loveman, 1991). Wyniki przeprowadzonych przez autorkę badań empirycznych pokazały, że w procesie uspołecznienia zadań oświatowych kluczowe okazywały się: a) sposób przekazania szkoły tj. przekazanie na podstawie umowy lub powołanie szkół prowadzonych przez podmiot niepubliczny po uprzedniej formalnej likwidacji; b) specyfika podmiotu niepublicznego, który podjął się realizacji zadań oświatowych; c) rola nauczycieli w środowisku lokalnym; d) potencjał i aktywność społeczna wspólnoty lokalnej oraz e) zaufanie do władz lokalnych. Wszystkie z tych czynników wymagają odrębnych, pogłębionych badań. $\mathrm{W}$ tym miejscu omówiony zostanie tylko pierwszy z nich.

Sposób uspołecznienia realizacji zadań oświatowych mógł mieć formę przekazania ich podmiotowi niepublicznemu (zgodnie z przepisa- 
mi art. 5 ust. 5g u.o.s.o) bez konieczności formalnej likwidacji. Jednak w wielu przypadkach gminy decydowały się na likwidację szkoły, przy czym proces ten poprzedzano nieformalnymi ustaleniami ze środowiskiem związanym ze szkołą i obietnicą pomocy przy dalszym prowadzeniu szkoły przez podmiot niepubliczny, o ile podejmie się realizacji tego zadania (wywiady: S/I/W, M/II/W; M/II/DS/N/ST1). Zastosowanie tego rozwiązania uzależnione było z kolei od pozycji władz lokalnych wśród społeczności, doświadczeń w zakresie współpracy międzysektorowej, a także aktywności i potencjału społeczności lokalnej w zakresie uczestnictwa w życiu publicznym.

Stworzona furtka prawna pozwalająca uniknąć całkowitej likwidacji szkoły i świadczenia usług edukacyjnych przez podmiot niepubliczny ma zalety, które wskazywane były również w przypadku uspołecznienia (prywatyzacji) innych usług publicznych. Zaliczyć do nich można m.in. oczekiwaną poprawę jakości usług, obniżenie kosztów ich świadczenia, poprawę efektywności zarządzania, możliwość wyboru dostawcy usług przez mieszkańców, a także konkurencję na lokalnym rynku usług (Hood, 1991, s. 4-5). Prywatyzacja usług niesie też szereg zagrożeń, do których zaliczyć można: nadużycia, korupcję przy zlecaniu zadań, brak pewności i trwałości dostawy usług czy jakość kosztem obniżenia ceny (Pollitt, 2003, s. 26-51; Bevir, 2009, s. 13-14). W wielu badanych gminach problemem okazało się być samo przekazanie szkoły, bowiem nie wszędzie spotkało się ono z akceptacją zarówno władz samorządowych, jak i społeczności lokalnej. Analizując ten problem wskazać można trzy scenariusze: a) władze lokalne nie brały pod uwagę przekazania szkoły i były nastawione wyłącznie na likwidację placówki (scenariusz nr 1 tzw. radyklany), b) władze lokalne same proponowały przekazanie realizacji zadań oświatowych pomiotom niepublicznym, co najczęściej było połączone z deklaracją wsparcia finansowego, organizacyjnego i przekazaniem budynków (scenariusz nr 2 tzw. partnerski), c) władze lokalne nie planowały przekazania, ale akceptowały (zazwyczaj chcąc uniknąć oporu społecznego) ewentualne utrzymanie szkoły i prowadzenie jej przez podmiot niepubliczny, co z kolei uzależnione było od potencjału, aktywności społeczności lokalnej oraz chęci do zaangażowania się w prowadzenie szkoły (scenariusz nr 3 tzw. koncyliacyjny).

Pierwszy scenariusz dotyczył najczęściej gmin z silną pozycją władz lokalnych (organu wykonawczego), które z uwagi na wysokie koszty i nieracjonalną sieć szkół redukcję liczby placówek uznały za najwłaściwsze rozwiązanie (wywiady: S/I/W; P/II/W; P/III/W; M/III/BW). Wła- 
dze tych gmin nie brały pod uwage przekazywania zadań oświatowych z uwagi na brak potencjału społecznego, brak woli społeczności lokalnej do angażowania się w taką działalność oraz fakt, iż w ich przekonaniu było to rozwiązanie połowiczne i tymczasowe. W praktyce nadal - przynajmniej częściowo - obciążające samorząd. Celem działań tych władz była pełna racjonalizacja polityki oświatowej gminy obejmująca kwestie finansowe (odciążenie budżetu gminy), reorganizację sieci szkół, a także zagospodarowanie mienia pozostałego po szkołach. Racjonalizacja była warunkiem dalszego rozwoju gminy i realizacji inwestycji.

Z kolei drugi scenariusz dotyczył gmin, w których z jednej strony widziano zasadność utrzymania istniejącej sieci szkół, a z drugiej obawiano się oporu społecznego ze strony rodziców oraz najbardziej opiniotwórczego i zdolnego do zmobilizowania społeczności lokalnej środowiska, jakie stanowili nauczyciele. Istotnym argumentem była też aktywność społeczności lokalnej przejawiająca się zaangażowaniem w ramach organizacji pozarządowych czy występowaniem oddolnych inicjatyw na rzecz wspólnoty lokalnej (wywiady: M/II/W, M/II/DS/N/ST1; S/I/W; $\mathrm{S} / \mathrm{I} / \mathrm{DS} / \mathrm{N} ; \mathrm{S} / \mathrm{I} / \mathrm{N} / \mathrm{ST}$ ). W takich sytuacjach władze samorządowe często proponowały pomoc na etapie tworzenia podmiotu niepublicznego, który miałby się zająć prowadzeniem szkoły (wyjazdy do gmin, w których takie rozwiązanie już funkcjonuje), albo zapraszały stowarzyszenia z zewnątrz zajmujące się prowadzeniem szkół na większą skalę (m.in. $\mathrm{P} / \mathrm{IV} / \mathrm{W} ; \mathrm{M} / \mathrm{IV} / \mathrm{W} ; \mathrm{M} / \mathrm{IV} / \mathrm{N} 2$ ). W tym przypadku racjonalizacja miała charakter głównie ekonomiczny, przy czym władze - z różnych względów - nie podejmowały radykalnych działań.

W przypadku trzeciego scenariusza kluczowym ogniwem pozostawali nauczyciele szkół przeznaczonych do likwidacji. Istniejący potencjał społeczny, aby mógł zostać spożytkowany wymagał organizacji, którą z kolei mógł zapewnić lokalny lider. Często taką rolę pełnili właśnie nauczyciele z uwagi na znajomość specyfiki zadań oświatowych oraz zasad zarządzania szkołą. Brak tego czynnika w zasadzie uniemożliwiał podjęcie takiej inicjatywy. Społeczność lokalna samodzielnie - pomimo chęci i deklaracji - nie była w stanie sprostać tak odpowiedzialnemu zadaniu, jakim jest prowadzenie szkoły. Najczęstszym powodem rezygnacji z uspołeczniania szkół - nawet w obliczu ich likwidacji - był właśnie brak lidera. Chodziło jednak o lidera, który wywodziłby się ze środowiska nauczycielskiego. Jak wskazała jedna respondentka ,potencjał był, ale zabrakło lidera, kogoś kto by to wszystko spiął i zarządził" (P/III/PS). Nie zawsze osoba, która sprawdziła się w innych obszarach działania na 
rzecz społeczności lokalnej, okazywała się być właściwa w przypadku realizacji zadań oświatowych (M/II/W, M/II/DS/N/ST1). Zaangażowanie nauczycieli było widoczne w przypadku badanych gmin tylko w sytuacji, gdy nie zapewniono im miejsc pracy w innych placówkach na terenie gminy. Brak alternatywy powodował, że włączali się w proces tworzenia podmiotu, który podjąłby się realizacji zadań, a nawet sami inicjowali jego powstanie, mając świadomość utraty pracy (M/II/DS/N/ST1, S/I/ $\mathrm{DS} / \mathrm{N} ; \mathrm{S} / \mathrm{I} / \mathrm{N} / \mathrm{ST}$ ). W tym przypadku - podobnie jak w przy pierwszym scenariuszu - celem była pełna racjonalizacja polityki oświatowej gminy. Władze podejmowały działania, nie oglądając się na podmioty społeczne i ich udział w realizacji zadań oświatowych. Ewentualne powstanie podmiotu niepublicznego, który podjąłby się prowadzenia szkoły (czy też zaangażowanie podmiotu $\mathrm{z}$ zewnątrz) traktowane było przez władze badanych gmin obojętnie i w praktyce nie wiązało się ze wsparciem ze strony gminy poza przekazywaniem subwencji (M/II/ST2; P/IV/DS; P/IV/KW; S/I/DS/N1; S/I/N2/ST).

\section{Wnioski}

O faktycznym uspołecznieniu polityk publicznych można mówić w sytuacji pełnego zaangażowania społeczności lokalnych w proces świadczenia usług publicznych i realizacji zadań, co wiąże się z ponoszeniem nakładów oraz ryzyka. Uspołecznienie rozumiane jako angażowanie się społeczności lokalnej w działalność ciał opiniodawczo-doradczych (np. rad rodziców czy rad szkół, a nawet rad oświatowych) ma często charakter pozorny, a jej wpływ na ostateczny kształt planowanej polityki publicznej jest znikomy i uzależniony od nastawienia władz lokalnych. Faktyczne uspołecznienie realizacji zadań publicznych może być przejawem racjonalizacji polityk publicznych. Przykładem może być opisana $\mathrm{w}$ niniejszym artykule realizacja zadań oświatowych przez podmioty niepubliczne, która w wielu przypadkach okazała się być ratunkiem dla szkoły zagrożonej likwidacją, a także istotnym wsparciem dla władz lokalnych, które z uwagi na konieczność ograniczenia kosztów były zmuszone zamykać nieekonomiczne placówki, mając świadomość konsekwencji społecznych swoich działań.

Przedstawione w tekście rozwiązanie pozwalające na przekazywanie szkół podmiotom niepublicznym w drodze umowy czy też możliwość prowadzenia szkół stowarzyszeniowych, po uprzedniej likwidacji przez 
władze gminy, można uznać za przejaw racjonalizacji polityki publicznej (oświatowej) w wymiarze ekonomicznym. Nie jest to jedyny wymiar procesów racjonalizacji. Niemniej jednak, przedstawione rozwiązania miały z jednej strony ograniczyć wysokie koszty jednej z polityk publicznych realizowanych na poziomie gminy, aby umożliwić rozwój jednostek terytorialnych $\mathrm{w}$ innych sferach. Zmiana organu prowadzącego szkołę - z pominięciem szeregu innych aspektów wynikających z takiego rozwiązania i konsekwencji - pozwoliła z jednej strony utrzymać szkołę, instytucję ważną dla społeczności wiejskich, a z drugiej ograniczyć koszty zadań oświatowych (głównie poprzez zmianę sposobu zatrudniania nauczycieli), co było niemożliwe w przypadku samorządów gmin.

Aktywny udział społeczności lokalnej (i jej sformalizowanych reprezentacji np. w formie stowarzyszeń) nie tylko doprowadził do zmiany organu prowadzącego, ale także do szeregu zmian społecznych w ramach wspólnot lokalnych, jak również zmiany relacji podmiotów społecznych z władzami lokalnymi. Rozwiązanie to w zasadzie zmienia także sposób postrzegania polityk publicznych, dotąd zarezerwowanych wyłącznie dla władz publicznych. Dywersyfikuje bowiem podmioty odpowiedzialne za świadczenie usług publicznych. Jednocześnie takie rozwiązanie pozwala użytkownikom tych usług na dokonywanie wyboru usługodawcy w oparciu o istotne dla niego kryteria np. jakość, cena czy sposób zapewnienia danej usługi, co w przypadku usług edukacyjnych wydaje się zasadne. Obecność podmiotów niepublicznych jako aktywnych dostarczycieli usług publicznych wydaje się nieunikniona. Nakłada to na władze lokalne dodatkowe obowiązki w procesie zarządzania publicznego. Jak wskazuje J. Hausner, realizacja polityk publicznych to istota zarządzania publicznego, która wymaga menedżerskiego podejścia, odpowiedzialności wobec wszystkich interesariuszy, ale także umiejętności organizacyjnych (w tym decyzyjnych) pozwalających na realizację założonych celów (Hasuner, 2008, s. 47). W tym zawiera się także umiejętność właściwego doboru partnerów niepublicznych, którzy aktywnie włączą się w proces realizacji zadań publicznych, przyczyniając się do poprawy ich jakości i zwiększenia efektywności dostarczania, przy jednoczesnym zmniejszeniu kosztów sektora publicznego.

Uspołecznienie rozumiane jako faktyczny udział społeczności lokalnych w świadczeniu usług publicznych, które wiąże się z długofalowym zaangażowaniem oraz ponoszeniem odpowiedzialności i ryzykiem wymaga aktywnej postawy, chęci działania, ale także wiedzy i umiejętności organizacyjnych i zarządczych. Pozornie prosty mechanizm przejęcia 
szkoły przez podmiot niepubliczny, zgodnie z obowiązującymi przepisami, faktycznie jest znacznie trudniejszy do przeprowadzenia o czym świadczy niewielka skala jego zastosowania. Efektywność procesu uspołecznienia realizacji zadań oświatowych uzależniona jest od szeregu czynników, a wśród nich nastawienia władz lokalnych i ich wizji polityki oświatowej, pozycji władz w środowisku lokalnym, kondycji finansowej gminy, a także aktywności i potencjału społeczności lokalnej, jak również doświadczeń dotychczasowej współpracy międzysektorowej.

\section{Bibliografia}

Benington J. (2007), Approaching Public Service Reforms, w: Reforming public services, red. J. Benington, National School of Government, The Stationery Office, London.

Bevir M. (2009), Key Concepts in Governance, SAGE, London.

Biernat S. (1979), Działania wspólne w administracji państwowej, Wrocław.

Dziemianowicz-Bąk A., Dzierzgowski J. (2014), Likwidacja szkót podstawowych oraz przekazywanie stowarzyszeniom. Kontekst, proces i skutki przemian edukacyjnych $w$ spolecznościach lokalnych na podstawie analizy studiów przypadku, Instytut Badań Edukacyjnych, Warszawa.

Gawroński H. (2010), Zarzadzanie strategiczne w samorzadach lokalnych, Oficyna a Wolters Kluwers business, Warszawa.

Goodman J. B., Loveman G. W. (1991), Does Privatization Serve the Public Interest?, "Harvard Business Review", https://hbr.org/1991/11/does-privatizationserve-the-public-interest, 6.06.2017.

Gozdowska E., Uryga D. (2015), Rada oświatowa w opiniach władz samorządowych $i$ środowisk zwiqzanych z lokalnq edukacjq - raport z badania, ORE, Warszawa.

GUS (2016), Oświata i wychowanie w roku szkolnym 2015/2016, Główny Urząd Statystyczny, Warszawa.

GUS 2015, Oświata i wychowanie w roku szkolnym 2014/2015, Informacje i opracowania statystyczne, GUS, Warszawa.

Hausner J. (2008), Zarzqdzanie publiczne, Scholar, Warszawa.

Herczyński J., Sobotka A. (2014), Diagnoza zmian w sieci szkót podstawowych i gimnazjów 2007-2012, Instytut Badań Edukacyjnych, Warszawa.

Hood Ch. (1991), A public management for all seasons?, „Public Administration”, vol. 69(1).

Kaczyńska A. (2017), Oświata i wychowanie jako zadanie publiczne gmin. Czynniki wptywajace na efektywność wydatków budżetowych, CeDeWu Warszawa.

Kapuścińska M. (2014), Partnerstwo projektowe $w$ realizacji zadań publicznych. Analiza stanu prawnego i dotychczasowych dobrych praktyk tworzenia part- 
nerstw projektowych. Ekspertyza, Projekt „Potencjat-Działanie-Rozwój: nowy wymiar wspótpracy Miasta Płocka i płockich organizacji pozarzqdowych", Płock.

Kopińska V. (2013), Pozór regulacji prawnych dotyczacych organów społecznych w szkole, w: Sprawcy i/lub ofiary działań pozornych w edukacji szkolnej, red. M. Dudzikowa, K. Knasiecka-Falbierska, Impuls, Kraków.

Kotarba B. (2014), Analiza wybranych elementów polityki oświatowej gmin, w: Samorzad w systemie demokracji obywatelskiej. Wybrane problemy, red. R. Kmieciak, Toruń.

Kozanecki P. (2016), Co by było, gdyby nie ,tysiqclatki”? (16.03.2016), http://wiadomosci.onet.pl/tylko-w-onecie/co-by-bylo-gdyby-nie-tysiaclatki/7t3nfs, 29.10.2017.

Kozińska-Bałdyga A. (2015), Zalety $i$ wady innych niż JST organów prowadzacych szkoły na terenie gminy, w: Mała szkoła - problem czy szansa? Poradnik dla samorzadowców, red. E. Tołwińska-Królikowska, Ośrodek Rozwoju Edukacji, Warszawa.

Kuratorium Oświaty w Lublinie, https://www.kuratorium.lublin.pl/pliki/akt/id_8244/ zal/Przekazanie.pdf, 29.10.2017.

Kuriański M. (2008), Ku poszerzeniu horyzontów polskiej szkoły: szkic historyczny edukacji: zagrożenia $i$ szanse, ,Saeculum Christianum: pismo historycznospołeczne", nr 15/1, ss. 193-221.

Kurzyna-Chmiel D. (2013), Oświata jako zadanie publiczne, Lex a Wolters Kluwer business, Warszawa.

Kurzyna-Chmiel D. (2012), Główne formy współdziałania samorzqdu terytorialnego $w$ wykonywaniu zadań oświatowych, w: Formy współdziałania jednostek samorzqdu terytorialnego, red. B. Dolnicki, Lex a Wolters Kluwers business, Warszawa.

Kwiatkowski S. M. (2008), Tendencje zmian w zarzqdzaniu oświata w Polsce i innych krajach Unii Europejskiej, w: Menedżer i kreator edukacji, red. Cz. Plewka, H. Bednarczyk, Instytut Technologii Eksploatacji - Państwowy Instytut Wydawniczy, Radom.

Kwieciński Z. (2011), Cztery i pót. Preliminaria - Liminaria-Varia, Wydawnictwo Naukowe DSW, Wrocław.

Leoński Z. (2006), Samorzad terytorialny w RP, Warszawa.

Lipka-Szostak K. (red.) (2012), Mała szkoła. Poradnik dla stowarzyszeń rozwoju wsi, FIO, Warszawa.

Majchrowicz-Jopek E. (2012), Wybrane problemy wykonywania zadań oświatowych przez jednostki samorzqdu terytorialnego, „Kwartalnik Kolegium Ekonomiczno-Społecznego Studia i Prace" (SGH), nr 4.

Majewska K. (2015), Umowa przekazania szkoły organowi niepublicznemu, w: Mała szkoła - problem czy szansa? Poradnik dla samorzqdowców, red. E. Tołwińska-Królikowska, Ośrodek Rozwoju Edukacji, Warszawa. 
Majewska K. (2015), Przekazanie szkoły innemu organowi prowadzqcemu - regulacje prawne, w: Mała szkoła - problem czy szansa? Poradnik dla samorząowców, red. E. Tołwińska-Królikowska, Ośrodek Rozwoju Edukacji, Warszawa.

Marzec-Holka K. (2015), Peryferie edukacyjne szkół wiejskich w warunkach niżu demograficznego, „Pedagogika Społeczna”, nr 3(57).

Mencel M. (2013), Po co i dla kogo sq rady szkoły? Spojrzenie z dwudziestoletniej perspektywy, w: Sprawcy i/lub ofiary działań pozornych w edukacji szkolnej, red. M. Dudzikowa, K. Knasiecka-Falbierska, Impuls, Kraków.

NIK 2015, Wykonanie wybranych zadań oświatowych przez jednostki samorzadu terytorialnego. Informacja o wynikach kontroli, KNO-4101-007-00/2014 nr ewid. 49/2015/P/14/027/KNO, Departament Nauki, Oświaty i Dziedzictwa Narodowego Najwyższej Izby Kontroli, Warszawa.

Ochnio E., Mate szkoty - lepsze niż inne?, „Echo katolickie”, http://fio.org.pl/index.php?option $=$ com_content $\&$ view $=$ article $\&$ id $=1350$ :male-szkoly-lepsze-niz-inne-echo-katolickie\&catid=135:media-o-nas-w-roku-2011\&Itemid=100067, 9.06.2017.

Odpowiedź podsekretarza stanu w Ministerstwie Edukacji Narodowej - z upoważnienia ministra - na interpelację nr 20537 w sprawie zapewnienia władzom samorzqdowym większej swobody decyzyjnej w zakresie przekazywania prowadzenia szkót podmiotom prywatnym, http://www.sejm.gov.pl/sejm7.nsf/ InterpelacjaTresc.xsp?key=7EDAFFCD, 9.06.2017.

Pęczkowski R. (2017), Problemy matych szkół. Edukacyjne wyzwania, Wydawnictwo Uniwersytetu Rzeszowskiego, Rzeszów.

Pilch T. (2007), Pedagogika społeczna wobec kryzysów świata wartości i instytucji, w: Pedagogika społeczna: podręcznik akademicki, t. 2, red. E. MarynowiczHetka, PWN, Warszawa.

Pollitt Ch. (2003), The Essential Public Manager, Open University Press, New York.

Śliwerski B. (2013), Diagnoza uspołecznienia publicznego szkolnictwa III RP w gorsecie centralizmu, Impuls, Kraków.

Strus D. (2016), Relacje między sektorem publicznym i sektorem pozarzadowym w sferze wykonania zadań publicznych, Teka Kom. Politol. Stos. Międzynar. - OL PAN, nr 11/3.

Sułkowski Ł. (2005), Epistemologia w naukach o zarzqdzaniu, PWE, Warszawa.

Szarfenberg R. (2016), Remunicypalizacja (rekomunalizacja) ustug publicznych, http://rszarf.ips.uw.edu.pl/pdf/remunicypalizacja.pdf, 15.06.2017.

Sześciło D. (2016), O powikłanej decentralizacji. Instytucjonalny krajobraz systemu ustug publicznych w Polsce, ,Zarządzanie Publiczne”, nr 4 (38).

Sześciło D. (2014), O watpliwościach wokół powierzania prowadzenia szkół samorzadowych, ,Samorząd Terytorialny”, nr 3.

Sześciło D. (2015), Samoobstugowe państwo dobrobytu. Czy obywatelska koprodukcja uratuje ustugi publiczne?, Scholar, Warszawa. 
Sześciło D. (2015a), Prywatyzacja prowadzenia szkół samorzadowych do poprawki (2.01.2015), Wolters Kluwer, http://www.samorzad.lex.pl/czytaj/-/artykul/ prywatyzacja-prowadzenia-szkol-samorzadowych-do-poprawki, 29.10.2017.

Sześciło D. (2015b), Współzarzadzanie jako koprodukcja usług publicznych, „Zarządzanie Publiczne", nr 1(31).

Tołwińska-Królikowska E., Wiejska szkoła ośrodkiem rozwoju, http://fio.org.pl/index.php?option=com_content\&view=article \&id=1327:wiejska-szkola-osodkiem-rozwoju\&catid=120:o-szkolach\&Itemid=100030, 9.06.2017.

Ustawa z dnia 7 września 1991 r. o systemie oświaty, Dz.U. 2004, Nr 256, poz. 2572 z późn. zm.

Waligórski K. (1997), Problemy uspołecznienia szkoły, „Studia Pedagogiczne”, $\mathrm{nr} 30$.

Wlaźlak K. (2010), Rozwój regionalny jako zadanie administracji publicznej, Oficyna Wolters Kluwers business, Warszawa.

ZNP, Ostatnie małe szkoty, http://www.znp.edu.pl/element/2281/Ostatnie_male_ szkoly, 2.06.2017.

\section{Privatization of educational tasks as a form of public policy rationalization on the local level}

\section{Summary}

Educational policy is currently one of the key public policies created and implemented at the local level in Poland. This is because of its cost intensity, specific form of organization, which combines the influence (and power) of local and central authorities, and the importance of education in the development of society and state. In the case of rural areas, an additional factor emerges, namely the role of rural schools in the life of local community which goes beyond education alone. Trying to face educational policy problems, municipal authorities undertake various rationalization activities. One of them is the privatization of educational tasks, understood as the inclusion of non-state actors in the process of implementing educational tasks. On the basis of the results of the quantitative and qualitative research conducted in Polish municipalities in three selected regions, the author presents the formal and legal conditions for the transfer of educational tasks to non-state actors, the scale of the privatization process, its forms, conditions and circumstances. The results of the study indicate that this process, despite apparently clear legal solutions, is not commonly applied and difficult to implement in municipalities. It requires engagement and willingness for cooperation of both public and social actors. The theoretical framework of the article is based on the concept of privatization and co-production.

Key words: educational policy, public policy, public services, privatization 
